\title{
Ideograms on the Pottery of the Bronze Age of the Dnipro-Don Region Culturogenesis and Rigveda Texts
}

\author{
Anatoliy Shcherban* \\ Department of History, Museology and Cultural heritage, Ukraine
}

Submission: April 10, 2019; Published: April 24, 2019

*Corresponding author: Anatoliy Shcherban, Kharkiv State Academy of Culture, Bursatskyi uzviz, 4, Kharkiv, Ukraine, 61057, Ukraine

Abstract

An overview of the main achievements in the research of ideographic images on the pottery of the III-II millennia BC in Dnipro-Don region. There was emphasized the possibility of comparing them with separate Rigveda texts..

Keywords: Dnipro-Don region; Bronze Age; Ideograms; Pottery; Rigveda

\section{Mini Review}

According to many researchers, the territory between the Dnieper and the Don (part of modern Ukraine and the Russian Federation) during the Bronze Age was a part of the region where emerged the Proto-Indo-European cultural traditions. In particular, this fact confirms the interpretation of the semantic of ideograms on the pottery. The fact of their existence has been proved by Vasily Gorodtsov in 1907 [1,2], and during the 1990s-2000s Vitaliy Otroschenko [3], Elena Zakharova [2] and Anatoly Shcherban [4-6] published well reasoned versions of interpretation of their meanings.

The expressive ideograms were found on the ceramics of Yamna, Babyno and Zrubna culturally-historical communities. The most ancient of them are dated by the time, close to the beginning of the third millennium $\mathrm{BC}$, the most recent are close to the middle of the second millennium BC. Most ideograms consist of various combinations of geometric and cross-sectional elements, in the number and sequence repetitions of some parts is seen the «calendar» symbolic. A small number of images contains anthropomorphic, zoomorphic or theriomorphic characters.

After analyzing the fact that the swastika-like and snake-like signs are included in the ideogram part and taking into account the significant probability of the Indo-Aryan origin of the carriers of the aforementioned archaeological cultures, for the interpretation of the ideograms were used the texts of Rigveda, the oldest collection of religious Indo-Aryan hymns which have preserved till nowadays. A peculiar «key» for comprehension of meaning was the image on a vessel by Zrubna culture (XVI-XIV centuries BC) from the burial 12 mound 1 necropolis Novoselitsa (Donetsk region, Ukraine). Olena Zakharova substantiated the hypothesis regarding the episode reflection of the myth about Indra's victo ry (marked with a swastika) over Vritra (transmitted by broken wavy line with rectangular links) [2]. Anatoly Shcherban interpreted similar plots in several vessels of mentioned archaeological community, as well as products of previous culture such as Babyno. In some vessels the image of another mythological plot was interpreted, the moment of «cows» release by a heroic deity (similar to the plot with Indra and Val) [6]. I also consider, that some compositions of the same time with cross-shaped symbols, the number of elements in which correlates with «calendar» numbers, is correlate to representations about the divine creatures like Indra. There were substantiated the hypothesis, that the aforementioned images were applied to separate religious ceremonial vessels for the purpose of carrying out the rites with the using of drinks, which should annually stimulate the «deity of light» to repeat the feats of victory over the pests.

More ancient ideographic compositions (one of them belongs to the Yamna cultural-historical community and several belongs to the catacomb cultural-historical community) do not contain distinct cross-shaped characters. However, their main ornamental zones dominated by the image of four arches, circles and nipple-like projections. Additional zones contained 7-element compositions. In particular, such ornaments were found on unfired or weakly fired vessels of «calcite» mass. There was formulated the hypothesis about the transfer of ideas about the goddess, similar to Aditi (the mother of Indra) and Adityas. Products themselves can be associated with utensils, similar by their functions to «ukhu».

Thus, the interpretation of ideographic images on the pottery of the Bronze Age of the Dnieper-Don region of cultural development allows us to come closer to understanding of some elements 
of the ideology of the Proto-Indo-European since its formation Although the aforementioned semantic reconstructions which made by researchers are not the only possible, I consider they are quite reliable in the current state of development of the methodology of semiotic research of ancient ideograms.

\section{References}

1. Gorodtsov VA (1907) Results of archaeological research in the Bakhmut district of the Yekaterinoslav province in 1903. Works of the XIII Archaeological Congress in Yekaterinoslav, Russia, 1: 211-285.

2. Zakharova EYu (2000) Vessels with signs of the Srubna community of the Late Bronze Age. Central Chernozem Publishing House, Voronezh, Russia.

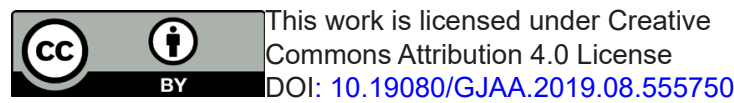

3. Otroshchenko VV (1998) The plot of reincarnation in the sign system of the tribes of the Zrubna community. Archaeological Almanac, Ukraine, 7: 93-98.

4. Shcherban AL (2017) Ideograms semantics on a clay pot from the Left-Bank Ukraine of the age of the chalcolithic. International journal. Culturology. Philology. Musicology, Ukraine, II(9): 36-40,.

5. Shcherban AL (2017) Transformations of the ceramic's ornamentation in the traditional culture of the population of the Left-Bank Ukraine (the end of the VII millennium BC - XIX century). Oleksandr Savchuk Press, Kharkiv, Ukraine.

6. Shcherban A (2017) Rigveda as a means of interpreting the ideograms on the ceramics of the Left-Bank Ukraine in the first half of the second millennium B. C. The Culturology ideas, Ukraine, 12: 135-142.

\section{Your next submission with Juniper Publishers will reach you the below assets}

- Quality Editorial service

- Swift Peer Review

- Reprints availability

- E-prints Service

- Manuscript Podcast for convenient understanding

- Global attainment for your research

- Manuscript accessibility in different formats

( Pdf, E-pub, Full Text, Audio)

- Unceasing customer service

Track the below URL for one-step submission https://juniperpublishers.com/online-submission.php 